\title{
Information Literacy Programmes Conducted by the Universities in Sri Lanka
}

Prasanna Ranaweera ${ }^{g}$

BA, ( J- Pura), MLS (Colombo)

\begin{abstract}
Information literacy has been defined as gaining the necessary skills required to access, process and present information for learning, research, problem solving and career development. The information literacy concept spreads across a vast span from user education programmes to knowledge extension or wisdom achievement. Mainly, information literacy skills are based on library skills and information technology skills. This paper discusses the value of information literacy programmes conducted by the universities in Sri Lanka in order to achieve the higher level of learning in the university sector; with special reference to Sri Lankan universities, with the focus on Outcome Space. The outcome space information literacy framework runs through Information sources, Information Technology, Information Control, Information Processing, Knowledge construction, Knowledge Extension and Wisdom as explained by Christine Bruce. Further the paper elucidates the information literacy initiatives commenced by the libraries of the University of Colombo, University of Kelaniya, University of Moratuwa, University of Sri Jayewardenapura and National Institute of Library and Information Sciences (NILIS). The survey results reveal that the information literacy programmes initiated by the university libraries and the Institute, range from user orientation to the credit based programmes. All the university libraries that were chosen for this study had commenced some sort of information literacy programme. But most of the programmes are at the lower level of the outcome space. Two university libraries and the Institute had made an attempt to initiate outcome space information literacy programmes.
\end{abstract}

Keywords: Information Literacy, Information skills, University Education, University Libraries

1. Introduction

Information literacy programmes in Sri Lankan universities have a very brief history. But many universities have initiated the basic and advanced

${ }^{g}$ Senior Lecturer, National Institute of Library and Information Sciences (NILIS), University of Colombo, E-mail prasanna@nilis.cmb.ac.lk 
information literacy programmes at different levels. Since 1980s, Information literacy has become very important in the higher education sector, throughout the world. But this concept came to be recognized and discussed in Sri Lanka as late as 2004, when NILIS organized an International Workshop on the topic, with the participation of foreign resource persons and delegates. Consequently the Empowering 08 information literacy model was formulated and came into practice. The Ministry of Education accepted the model and initially introduced it to the school sector practices in 2005. Subsequently training under this new model was provided for teacher librarians, teachers, principals and educational directors as a collaborative project by the NILIS and the School library Development Unit (SLDU) of the Ministry of Education. However, in the universities the concept was developed in an unorganized manner. Several individual university libraries have attempted to address the issue separately, without any motivation or a collaborative effort. This study attempts to obtain a clear picture regarding these programmes and how they could be improved. This study was carried out between January and March 2009 .

\section{Objectives of the study}

This study was carried out in order to achieve the following objectives.

1. To examine the importance of helping to deliver information literacy skills in the university sector in Sri Lanka by reviewing the current literature.

2. To investigate the current information literacy programmes carried out by the university libraries of Sri Lanka

3. To analyze and evaluate the current scenario of information literacy programmes of the selected university libraries

\section{Survey sample}

There are eighteen well established universities in Sri Lanka funded and maintained by the Government of Sri Lanka.

For this study the author selected only 05 universities and one Institute, due to the availability of resources and time. They were namely;

1. University of Colombo

2. University of Kelaniya 
3. University of Moratuwa

4. University of Sri Jayawardhanapura

5. Open University of Sri Lanka

6. National Institute of Library and Information Sciences (NILIS)

University of Colombo. (NILIS was selected for the study as it initiated a new information literacy model called Empowering 08 and practiced it for its courses)

The survey Research Method was used in carrying out this study. Questionnaires interviews and observation techniques were used to collect the data.

\section{Background to the study}

The author has gained much exposure to the information literacy concept and the programme since he joined NILIS, University of Colombo as a senior lecturer in June 2005. The researcher is conducting lectures in several areas of the subject Information Literacy, and has received the opportunity to participate in several training programmes as well. NILIS introduced the information literacy programmes stand alone, as well as collaboratively with the curriculum. These integrated Information Literacy programmes were initially introduced by the NILIS staff to students of the $2006-2007$ batch following the Post-graduate Diploma in Teacher Librarianship (PGTL).

According to Wijethunga, (2008) "The orientation programme is based on an assignment topic chosen by the module lecturer. Using the eight components of the empowering 8 model, learners are taken through the process of defining the topic to creating and assessing the results. To guide the students variety of check lists, activity sheets and guide lines are provided"

The teaching staff, Asst.librarian \& administration of NILIS contribute to the collaborative Information Literacy programmes in order to obtain the maximum results. As a pilot project the information literacy program was introduced to the Postgraduate Diploma in Teacher Librarianship (PGTL) students 32 using forty class room contact hours. The information literacy sessions were 
specified from topic selection to assessment. The final outcome of the programme was included as one assignment of the main subject.

\section{Literature Survey}

\section{Definition of information literacy}

In this study the following definitions were taken into consideration.

Association of College and Research Libraries has defined Information Literacy as:-

"Recognize when information is needed and have the ability to locate, evaluate, and use effectively the needed information" (ACRL, 2000)

ACRL further defines Information literacy as "Information literacy forms the basis for lifelong learning. It is common to all disciplines, to all learning environments, and to all levels of education. It enables learners to master content and extend their investigations, become more self-directed, and assume greater control over their own learning. An information literate individual is able to:-

- Determine the extent of information needed

- Access the needed information effectively and efficiently

- Evaluate information and its sources critically

- Incorporate selected information into one's knowledge base

- Use information effectively to accomplish a specific purpose

- Understand the economic, legal, and social issues surrounding the use of information, and access and use information ethically and legally" (ACRL ,2000)

This definition and explanation given by ACRL is considered as the foundation for the world wide concept of information literacy. It explains very clearly what information literacy is. Therefore many information literacy experts consider this definition as the foundation for all the information literacy educational programmes.

Further, Charted Institute of Library and Information Professionals (CILIP) has defined information literacy based on the ACRL definition, in the context of problem solving and information society. 
"Information Literacy encompasses knowledge of one's information concerns and needs, and the ability to identify, locate, evaluate, organize and effectively create, use and communicate information to address issues or problems at hand; it is a prerequisite for participating effectively in the Information Society, and is part of the basic human right of life long learning." (US National Commission on Library and Information Science, 2003).

When the above definition is broken down into its practical aspects basically, information literacy skills in university education run through from problem identification, defining the research topic, identifying the probable information sources, searching capabilities via internet databases and other sources, evaluating the found information, writing, presentation or using the accessed information in academically, avoiding plagiarism and using the proper referencing style etc.

The above idea has been explicitly explained by Bundy (2004), by dividing information literacy in higher education into three categories.

(1) Generic skills (2) Information skills (3) Values and beliefs

\section{Generic skills}

Problem solving

Collaboration

Team work

Communication

Critical thinking

\section{Information skills}

Information seeking

Information use

Information technology fluency

\section{Values and beliefs}

Using information wisely and ethically

Social responsibility

Community participation

With this division it is clear that information literacy skills are not merely a set of skills, but those which direct the university students towards self directed life 
long learners, better problem solvers, and effective decision makers, by creating an information literate society.

Information literacy and learning are interrelated and most of the time the final objectives are the same. Therefore information literacy skills and models can be identified as one of the learning systems in order to achieve the ultimate goal. The following figure explains it very clearly.
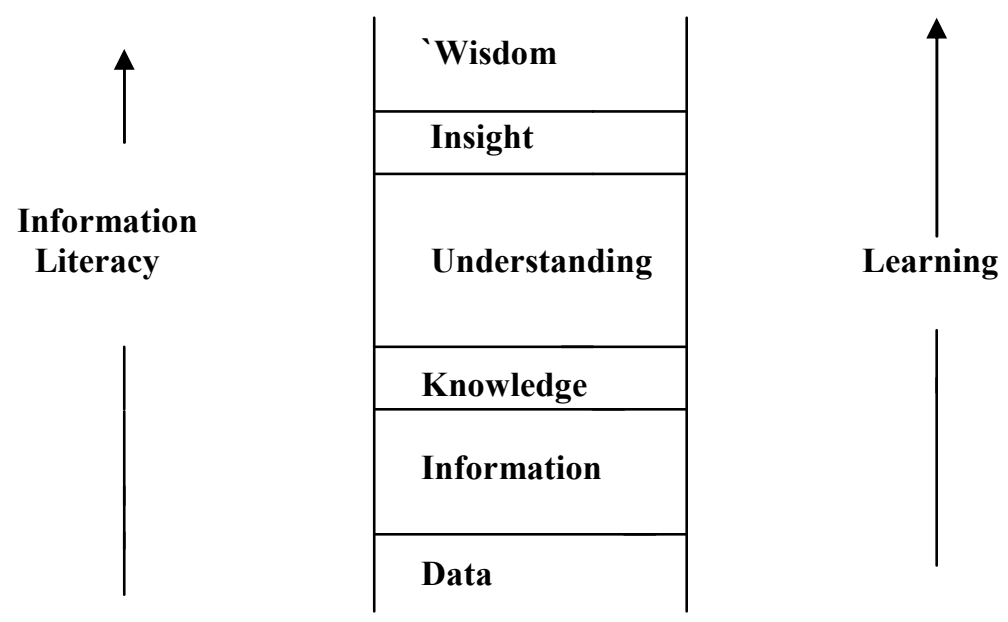

Figure 01 - Information literacy and learning.

Source: Reflective Internet Searching: An action research model by Edwards, and Bruce (2002).

Here the students in the universities are directed from accessing data to reaching wisdom level, with the help of information literacy pathways.

Types of information literacy programmes that carried out by the Foreign and Local Universities

When the author studied the information literacy programmes conducted by the foreign universities, he was able to identify the following:

1. Generic information literacy skills or stand alone information literacy skills courses

2. Parallel (extra curricular but compliment specific subject area) courses related to information literacy 
3. Integrated or embedded: Subject specific information literacy courses. Integrated with co-curriculum, a specific discipline or course on general information skills.

4. For credit to non credit courses.

5. From required to elective courses.

6. From distance to face to face courses.

7. Online Information Literacy Instructions (Web based guide)

In addition to the various types of information literacy courses, some specific characteristics of successful information literacy instruction programs are specified by Abbey \& Michael as follows.

- Use of student centered, active and collaborative learning methods

- Adherence to instructional design principles during planning

- Relevance to particular course goals and ultimately the overall curriculum

- Formation of partnerships between library, faculty and other campus departments

- Support of faculty learning and development

- Scalability for large numbers of students" Abbey \& Michael, (2002).

Following are the main areas of the information literacy programmes and information literacy courses, conducted by the five main university libraries and the institutes, in which the author carried out this study.

How to locate resources, Information resource selection, Searching electronic data bases, Search strategies, Data base searching, Internet searching and source evaluation, Critical evaluation of information, How to avoid Plagiarism, Academic integrity, Academic writing and preparing Research proposal,

The following quotation by Skagen, T. \& Blaabjerg, N.J (2006) explains very clearly, the similarities between Information literacy and Learning among stake holders.

"Librarians talk about information literacy, search strategies, Boolean operators, information seeking behaviour, key words and information 
resources. The faculty talks about academic competencies, methodology, problem definitions, research, the use of sources and argumentation. The students talk about writing a project report, the need for relevant material, their problem definition and how to move forward in their process and about frustrations in their writing process and information seeking. The libraries need to move towards faculties, academic discourses and explain the library's role in the faculty's own terminology." (Skagen, \& Blaabjerg, 2006).

According to the above quotation the university library too plays a vital role in collaborating and leading action in research, teaching and learning.

\section{Seven faces of Information literacy in higher education}

Seven faces of Information literacy in higher education was invented by Christine Bruce when she carried out her Ph D study, in order to understand the way in which higher educators experience information literacy. The same seven categories are the basis for the outcome space information literacy framework.

1. The information technology conception

2. The information sources conception

3. The information process conception

4. The information control conception

5. The knowledge construction conception

6. The knowledge extension conception

7. The wisdom conception (Bruce, 1997)

"The outcome space suggests that it would be possible to detail the various ways of thinking about information literacy, to which any curriculum attends, in a way which reveals the cluster of categories embedded in that curriculum. A curriculum which addressed students' familiarity with information sources and information technology without addressing the processes of recognizing information needs, locating, evaluating and using information could be graphically portrays as in figure" (Bruce, 1997) 


\begin{tabular}{|l|l|}
\hline $\begin{array}{l}\text { Knowledge } \\
\text { Extension }\end{array}$ & \multicolumn{1}{c|}{ Wisdom } \\
\multicolumn{1}{|c|}{ Knowledge construction } \\
Info. control $\quad$ Info. process \\
$\qquad \begin{array}{l}\text { Info sources } \\
\text { Information } \\
\text { Technology }\end{array}$ \\
\hline
\end{tabular}

Figure 2 - The outcome space: The Seven Faces of Information Literacy, (Bruce, 1997)

The outcome space framework serves as a useful guide for the information literacy curriculum of the university sector too. If this framework is applied to the information literacy curriculum, there will be a satisfactory balance between each area of the curriculum. The author has observed mainly the information literacy programmes in Sri Lankan Universities and has comprehensively covered the areas of information sources, information technology and information process. The areas of information control, knowledge construction, knowledge extension and wisdom conceptions have not been comprehensively covered.

Information technology skills are essential in order to enable students to retrieve information, communicate information and publicize information. Students need to be more proactive, in order to grasp the new information technology knowledge which undergoes continual change. Information sources are the places where the information is stored. These sources may be in different forms and formats. Therefore it is essential that the students have a good knowledge about information sources and using them freely. The study revealed that the information literacy courses conducted by Sri Lankan universities had successfully covered this category. 
Information process relates to acquisition of information and using information for problem solving and decision making. In the information literacy programmes included in this research, the acquisition of information skills was practiced; but the usage of information in problem solving and decision making was not adhered to completely.

Information control means acquiring the necessary skills by the students, to file or organize the retrieved information, and to use it in the future. This is another aspect that information literacy course designers need to think about.

Knowledge construction is one of the main objectives of the university students. Students use the knowledge gained by them, to construct new knowledge with new interpretations. This is the pathway for the development of the country. Unfortunately the information literacy educational programmes in Sri Lanka have so far not covered this concept. Knowledge extension concept means using knowledge to solve problems, and to acquire new vision using the knowledge.

Achieving "Wisdom" through information literacy is the ultimate goal of the university student. The wisdom conception is associated with good values, attitudes and beliefs. This means that students or citizens use information for the benefit of others. When librarians design the information literacy curriculum, attention should be focused on this scenario too.

The information literacy programmes carried out by the universities of Sri Lanka 
Table 1 - Information Literacy programmes at Universities

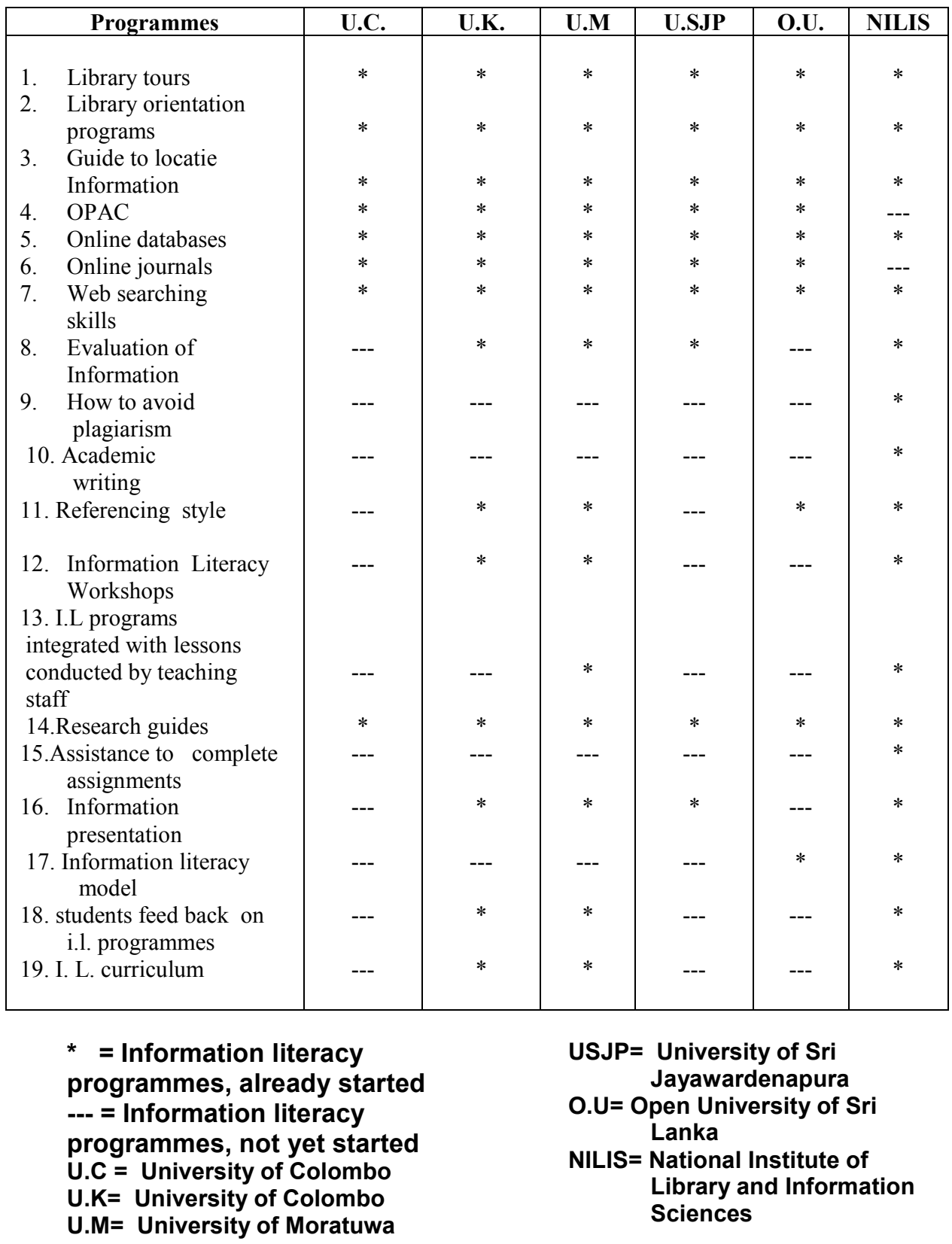

The table 1 can be explained in detail as follows.

1. The main library of the University of Colombo has been carrying out the following programmes in order to improve the students' information literacy skills. Library tours, Library orientation programs, 
Guide to locate Information, OPAC, Information searching skills for On-line databases, Online journals, Web searching and Research guides etc.

2. The main library of the University of Kelaniya, has been carrying out the following programmes. Library tours, Library orientation programs, Guide to locate Information, OPAC, Information searching skills for On-line databases, Online journals, Web searching, Research guides, Evaluation of information, Referencing style, Information literacy workshops and Information presentation etc.

3. The main library of the University of Moratuwa has been carrying out the following programmes. Library tours, Library orientation programs, Guide to locate Information, OPAC, Information searching skills for On-line databases, Online journals, Web searching, Research guides, Evaluation of information, Referencing style, Information literacy workshops, I.L. programmes integrated with lessons conducted by teaching staff, Getting students' feedback, Using the I.L. curriculum and Information presentation, etc.

4. The main library of the Open University of Sri Lanka, has been carrying out the following programmes. Library tours, Library orientation programs, Guide to locate Information, OPAC, Information searching skills for On-line databases, Online journals, Web searching, Research guides, Referencing style, Getting students' feedback and Using the I.L. Model etc.

5. The main library of the University of Sri Jayewardenapura, has been carrying out the following programmes. Library tours, Library orientation programs, Guide to locate Information, OPAC, Information searching skills for On-line databases, Online journals, Web searching, Research guides, Evaluation of information and Information presentation etc. 
6. NILIS, University of Colombo has been carrying out the following programmes. Library tours, Library orientation programs, Guide to locate Information, Information searching skills for On-line databases, Online journals, Web searching, Research guides, Evaluation of information, Academic writing, Referencing style, Information literacy workshops, I.L. programmes integrated with lessons conducted by teaching library and administrative staff, Assistance to complete assignments, Information presentation Getting students' feedback, Using the I.L. curriculum and Empowering 08 I.L. model etc.

The following figure depicts the information literacy programmes that are carried out by the university libraries.

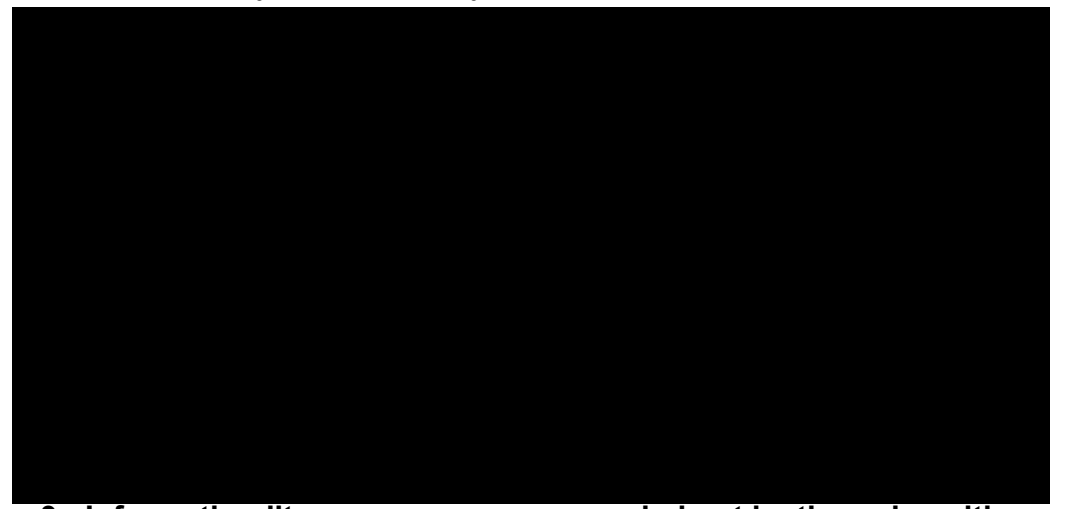

Figure 3 - Information literacy programmes carried out by the universities

Integration of information literacy into curriculum is accepted as the best way to implement the information literacy programmes in order to achieve the best results.

"Curriculum integration is the best approach for developing information literacy because it aids in student centered learning at point of need." Integration into the curriculum provides all students with an equal opportunity to become information literate" (Information literacy academic staff, 2006)

Most of the university libraries have already commenced their information literacy programmes under the same name or under other names. But the author discovered that the collaborative programmes with the integration of 
the faculty and the administration; or integration of information literacy into curriculum; is lacking in the Sri Lankan university sector. Integration of information literacy into the curriculum with collaboration of teaching faculty and administrators is a new concept in the Sri Lankan context. The following figure shows the current scenario under the collaborative information literacy programmes in the universities.

Figure 4 - Information literacy programmes that collaborated with the faculty and administrators

\section{Conclusion}

The study revealed that all the librarians who were interviewed were very keen and enthusiastic to commence information literacy programmes in collaboration with the teaching faculty. They stated that they faced several problems too such as lack of resources, lack of trained staff, and proper guidance. On the whole all the libraries and library staff included in the sample had taken satisfactory steps to initiate information literacy programmes in their particular libraries.

According to the above data it is clear that in order to achieve the best information literacy practices by the Sri Lankan Universities, they have to plan and implement more information literacy programmes integrated with the curriculum, to enable the students' to gain knowledge extension and wisdom. Therefore the librarians and teaching staff need to work in collaboration to develop the information literacy programmes with instructional strategies, assessment techniques and applying an information literacy model. 


\section{References}

Abby, K., \& Michael, P. (2002). Information Literacy Instruction in Higher Education: Trends and Issues. ERIC Digest.

Association of college and research libraries. [ACRL] (2000). information literacy competency standards for higher education. Retrieved February 10, 2009 from http://www.ala.org/ala/mgrps/divs/acrl/standards/informationliteracycomp etency.cfm\#ildef

Blackall, C. (2001). Rethinking Information Literacy in Higher Education: The case for Informatics

Bruce, C. (1997) The Seven Faces of Information Literacy. Auslib. Blackwood.

Bundy, A. (ed.) (2004) Australian and New Zealand Information Literacy Framework principles, standards and practice. 2nd ed. Adelaide: Australian and New Zealand Institute Information Literacy.

Edwards, S., \& Bruce, C. (2002), Reflective Internet Searching: An action research model, The learning organization, 9 (3/4), 180 - 188.

Information Literacy Academic Staff. (2006) Retrieved January 12, 2009 from www.library.auckland.ac.nz/instruct/docs/academic.pdf

Mohd, S. S. \& Zainab, A. N. (2002). Information Literacy Programs in Malaysian Public Universities: An Observation. Conference paper presented at $68^{\text {th }}$ IFLA Council \& General Conference. August 2002.

Skagen, T., \& Blaabjerg, N. J. (2006). Empowering Students Theory Information Literacy in the psysical and virtual class rooms. Creating knowledge IV. Copenhagen 16-18 (2006)

US National Commission on Library and Information Science. (2003) The Prague Declaration: 'Towards An Information Literate Society' Retrieved February 10, 2009 from http://www.cilip.org.uk/getinvolved/advocacy/learning/informationiteracy/Pages/introduction.aspx Visited 10.02.2009

Wijethunga, P. (2008). Improving Information Skills of the Postgraduate Students of NILIS University of Colombo. DESIDOC. Journal of Library and Information Technology, Vol 28 No 02. 2008. pp 18 - 27 